\title{
ASSESSING EFFICIENCY OF THE CONIFEROUS ENERGY SUPPLEMENT IN THE DIET OF DAIRY COWS FOR MAINTAINING PRODUCTIVE HEALTH
}

\section{NADEZHDA VLADIMIROVNA BOGOLYUBOVA ${ }^{1 *}$, VASILY PAVLOVICH KOROTKY ${ }^{2}$, ALEXANDER SERGEYEVICH ZENKIN ${ }^{3}$, VIKTOR NIKOLAEVICH ROMANOV ${ }^{1}$, VIKTOR ANATOLYEVICH RYZHOV ${ }^{2}$}

\begin{abstract}
${ }^{1}$ Department of Physiology and Biochemistry of Farm animals, Federal State Budgetary Scientific Institution, Dubrovitsy, 60, Podolsk 142132, Moscow Oblast, Moscow., ${ }^{2}$ Science and Technology Center "Khiminvest" Ltd., Nizhne-Volzhskayanaberezhnaya, Nizhny Novgorod, 603001, Russia. ${ }^{3}$ Department of Morphology, Physiology and Veterinary Pathology, Mordovia Ogarev State University, Saransk, Republic of Mordovia, 430005, Russia. Email: 652202@mail.ru
\end{abstract}

Received: 12 May 2017, Revised and Accepted: 16 June 2017

ABSTRACT

Objective: This study was aimed at assessing efficiency of the original coniferous energy supplement in the diet of cows at the end of the dry period - beginning of lactation - for improving the energy density of diets, enriching them with vitamins and major and minor nutrient elements, improving milk productivity, and maintaining productive health.

Methods: The scientific-production experiment was performed on the basis of the "Lukoshkino" unit of the "Klenovo-Chegodaevo" research farm (Moscow) on twenty cows. The preparation was fed at the rate of $150 \mathrm{~g}$ for 20 days before calving and for 30 days after calving.

Results: Studies have found the positive effect of the preparation on the average daily milk yield, natural fat content increased by 5.4\%-6.9\% (with butterfat percentage increased by $0.09 \%$ ), and reduced cost of feed per unit of obtained product.

Conclusion: The use of the preparation promoted enzymatic processes in the rumen, had positive effect on the carbohydrate-lipid and protein metabolism, and had no negative effect on the non-specific resistance of cows.

Keywords: Highly productive cows, Pine energy supplement, Milk yield, Milk quality, Hematological and biochemical status, Resistance.

(c) 2017 The Authors. Published by Innovare Academic Sciences Pvt Ltd. This is an open access article under the CC BY license (http://creativecommons. org/licenses/by/4. 0/) DOI: http://dx.doi.org/10.22159/ajpcr.2017.v10i10.19860

\section{INTRODUCTION}

Productivity of dairy cattle is associated with intensity of all types of metabolism in the organism. With the optimal state of metabolic processes, the genetic potential of highly productive animals is implemented to the fullest extent, and productive health is maintained. The feature of metabolism in high-producing cows in the period of trying to obtain a higher milk yield is the fact that the high energy requirement for milk formation may not be fully covered by the nutrients that come from food, it causes the state of relative hunger in them. As a result, lipids of fat depots, muscle tissues, proteins, and minerals of own body accumulated by the animals during the second half of lactation, especially in the dry period[1-3], are used for milk synthesis in this period in significant quantities. Many researchers tend to believe that in case of high level of productivity, the normal course of lipid metabolism in the organism of cows is limited by the lack of glucose, which in large quantities is spent on milk lactose synthesis. Therefore, to increase glucose concentration in blood and to normalize the metabolic processes, various glycogenic feed additives are used, including propylene glycol, salts of propionic acid, and glycerin[4]. In the domestic market, the basis for energy additives is mostly propylene glycol, while in Europe, glycerin is successfully used. The main component of glycerin is glycerol. Glycerol interacts with many compounds, is harmless to the environment, and is not dangerous to the soil and the groundwater. This scientific paper is focused on studying this area.

\section{METHODS}

The research, development, and production experimentwere performed in the period between September and November 2016 with two groups of cows of the black motley breed chosen by the principle of analogs in productivity and lactation. Each group contained ten animals: Group 1 was a reference one (did not receive the preparation), and in Group 2, animals received the coniferous energy supplement (CES) in the basic diet in the dosage of $150 \mathrm{~g}$ every day for 20 days before and 30 days after calving. Animals in both groups were kept in the same conditions. Animal diets were prepared in accordance with their live weight and yield (Table 1).

In the experimental cows, milk production and milk quality, parameters of rumen fermentation, biochemical and hematological blood characteristics, and some indicators of non-specific immunity were studied. The gross and average daily milk yield was calculated on the basis of reference milking of all experimental animals. To determine milk quality in experimental animals, average samples of milk were taken, and the following was determined in them: Mass fraction of fat, protein, lactose, and non-fat milk solids. In stabilized blood, total protein, albumin, globulin, creatinine, urea, total bilirubin, total cholesterol, calcium, phosphorus, alkaline phosphatase, glucose, alanine aminotransferase (ALT), and aspartate aminotransferase (AST) were determined. In whole blood, level of hemoglobin, number of erythrocytes, lymphocytes, and hematocrit were determined. Lysozyme activity in blood serum (LABS) and bactericidal activity in blood serum, level of lysozyme, and opsonocytophagic response were also determined. For characterization of rumen digestion in animals, parameters of rumen fermentation - $\mathrm{pH}$, total volatile fatty acids (VFAs), molar ratio of certain fermentation acids, ammonium nitrogen concentration, and the content of microbial mass (bacteria and infusoria) were determined in the content of rumen.

\section{RESULTS}

Information about milk productivity and milk quality is summarized in Table 2. 
Table 1: Diets of experimental dairy cows

\begin{tabular}{lll}
\hline Fodders and indicators & Group & \\
\cline { 2 - 3 } & Reference & Experimental \\
\hline Haylage of perennial grasses, kg & 19,000 & 19,000 \\
Corn silage, kg & 15,000 & 15,000 \\
Grass-and-legume hay, kg & 3000 & 3000 \\
Combined fodder, kg & 7.0 & 7.0 \\
Molasses, kg & 0.8 & 0.8 \\
CES, g & - & 150 \\
\hline
\end{tabular}

CES: Coniferous energy supplement

Table 2: Milk yield in experimental animals, milk quality $(n=10, M \pm m)$

\begin{tabular}{|c|c|c|}
\hline \multirow[t]{2}{*}{ Indicator } & \multicolumn{2}{|c|}{ Group of animals } \\
\hline & Reference & Experimental \\
\hline \multicolumn{3}{|l|}{ On the $30^{\text {th }}$ day of the experiment } \\
\hline Average daily milk yield, kg & $30.6 \pm 3.8$ & $32.7 \pm 2.3$ \\
\hline Percentage of reference & 100.0 & 106.9 \\
\hline Percentage of fat & $3.86 \pm 0.25$ & $3.95 \pm 0.02$ \\
\hline Percentage of protein & $3.03 \pm 0.06$ & $3.03 \pm 0.08$ \\
\hline Percentage of lactose & $5.02 \pm 0.04$ & $5.01 \pm 0.06$ \\
\hline Percentage of NFMS & $12.9 \pm 0.27$ & $13.41 \pm 0.19$ \\
\hline $\begin{array}{l}\text { Number of somatic cells, } \\
\text { thousand } / \mathrm{cm}^{3}\end{array}$ & 1200.8 & 490.0 \\
\hline Gross yield for the period, kg & 918 & 981 \\
\hline Milk fat yield, $\mathrm{kg}$ & 35.43 & 38.75 \\
\hline Gross milk yield of 3.4\% milk, kg & 1042.2 & 1139.7 \\
\hline Average daily yield of $3.4 \%$ milk, kg & 34.74 & 37.99 \\
\hline \multicolumn{3}{|l|}{$\begin{array}{l}30 \text { days after the experiment was } \\
\text { stopped }\end{array}$} \\
\hline Average daily milk yield, kg & $31.3 \pm 1.0$ & $33.0 \pm 1.22$ \\
\hline Percentage of reference & 100.0 & 105.4 \\
\hline Percentage of fat & $3.68 \pm 0.13$ & $3.77 \pm 0.1$ \\
\hline Percentage of protein & $2.99 \pm 0.14$ & $2.99 \pm 0.14$ \\
\hline Percentage of lactose & $4.93 \pm 0.21$ & $4.98 \pm 0.09$ \\
\hline Percentage of NFMS & $12.71 \pm 0.43$ & $12.79 \pm 0.48$ \\
\hline $\begin{array}{l}\text { Number of somatic cells, } \\
\text { thousand } / \mathrm{cm}^{3}\end{array}$ & 1725.0 & 147.4 \\
\hline Gross yield for the period, kg & 939 & 990 \\
\hline Milk fat yield, $\mathrm{kg}$ & 34.55 & 37.32 \\
\hline Gross milk yield of 3.4\% milk, kg & 1016.3 & 1098.0 \\
\hline Average daily yield of $3.4 \%$ milk, $\mathrm{kg}$ & 33.9 & 36.6 \\
\hline \multicolumn{3}{|l|}{ On the average for 2 months } \\
\hline Average daily milk yield, kg & $30.95 \pm 1.9$ & $32.85 \pm 1.2$ \\
\hline Percentage of fat & $3.77 \pm 0.14$ & $3.86 \pm 0.06$ \\
\hline Gross yield for the period, kg & 1857 & 1971 \\
\hline Milk fat yield, kg & 70.0 & 76.1 \\
\hline Gross milk yield of 3.4\% milk, kg & 2059 & 2237.7 \\
\hline $\begin{array}{l}\text { Average daily yield of } 3.4 \% \text { milk, } \mathrm{kg} \\
\text { Cost of fodder per } 1 \mathrm{~kg} \text { of } 3.4 \% \\
\text { milk }\end{array}$ & 34.3 & 37.3 \\
\hline Concentrates, g & 204.0 & 187.7 \\
\hline
\end{tabular}

As the table shows, the use of CES in the fodder increased milk production. The average daily milk yield on the $30^{\text {th }}$ day of the experiment with natural fat content and after transferring to the fat content of $3.4 \%$ in cows of the experimental group was higher by $6.9 \%$ and $9.3 \%$, respectively, as compared to animals in the reference group. A higher fat content (3.95\%) was observed in cows in the experimental group versus $3.86 \%$ in the animals in the reference group. After administration of the preparation had been discontinued, the average daily milk yield in experimental cows also remained higher than that in the animals from the reference group.

The content of protein and lactose in milk from the cows in both groups was almost identical. A considerable reduction was noted in the number of somatic cells in milk from cows that received CES, which may be due to the bactericidal action of conifer the preparation. A trend to increasing the content of dry milk solids in the milk from experimental cows has been noted.

The cost of nutrients for production of $1 \mathrm{~kg}$ of $3.4 \%$ milk in groups of cows that received CES was the lowest. Hence, in cows from the experimental group, consumption of concentrated fodder was lower by $8.0 \%$, as compared to the animals in the reference group.

Biochemical parameters of cows have been statistically processed, summarized, and presented in Table 3.

It should be noted that all animals in the experiment were healthy, with biochemical and hematological parameters of blood within the acceptable physiological norms. At the end of the experiment, it was also noted that all biochemical parameters were within the limits of the physiological norm. However, some differences were observed in the changes in biochemical parameters in the reference and experimental animals. Thus, the experimental cows had a decreased level of protein in the serum, mainly due to globulins. This may be due to the increased milk production by experimental cows and the absence of diet correction due to increased milk productivity. In cows that received CES, a tendency to increasing concentration of albumin $(5.5 \%)$ in blood, decreasing concentration of globulins (by 7.4\%), and urea content $(27.2 \%)$ was observed. The latter may be the evidence of increasing assimilation processes. Concentration of creatinine in blood of cows in the experimental group was lower by $5.2 \%$ than that in the reference group, which may also be the evidence of intensive nitrogen metabolism in experienced cows.

In the blood of cows that received CES, no significant difference was noted in changing the amount of transamination enzymes - ALT and AST. An increased amount of these enzymes is usually a symptom of liver disorders. Consequently, the use of CES does not result in liver disorders.

The level of cholesterol in cows that received CES in the diet was by $26.3 \%$ lower, as compared to the animals in the reference group, which may indicate metabolism intensification in experimental animals. The level of glucose in experimental cows was by $9.5 \%$ higher than in the animals from the reference group. However, fluctuations of this indicator were within the physiological norm; therefore, these changes may be due to the fodder issues.

Information about content of macroelements in the blood of experimental cows is shown in Table 4.

According to the table, no significant difference has been noted in the content of certain macroelements in the blood of cows that received CES and the animals from the reference group.

Hematological parameters are summarized in Table 5.

In general, the analysis of hematological parameters indicates that no significant difference has been noted between the cows that received and those that did not receive CES. However, in the blood of the experimental animals, a higher content of hemoglobin (5.8\%), hematocrit $(1.7 \%)$, and erythrocytes $(1.8 \%)$ and low content of leukocytes were found, as compared to the cows in the reference group. This may be an evidence of the harmlessness of the preparation and of maintaining productive health in its use.

Table 6 summarized the information about indicators of non-specific resistance in experimental animals.

Analysis of the data in Table 7 shows that cows in the experimental group had the increased by $70.0 \%$ percentage of LABS, as compared to the reference group. In cows that received CES, phagocytic activity (PA) 
Table 3: Biochemical parameters of experimental animals' blood

\begin{tabular}{lll}
\hline Indicator & Group & \\
\cline { 2 - 3 } & Reference & Experimental \\
\hline Total protein, g/L & $87.3 \pm 0.85$ & $84.2 \pm 0.83^{*}$ \\
Albumens, g/L & $26.1 \pm 1.43$ & $27.55 \pm 0.43$ \\
Globulins, g/L & $61.2 \pm 1.94$ & $56.65 \pm 0.99^{*}$ \\
Albumens/globulins ratio & 0.43 & 0.49 \\
Urea, mM/L & $4.49 \pm 0.33$ & $3.27 \pm 0.45$ \\
Creatinine, $\mu$ M/L & $71.2 \pm 1.54$ & $67.5 \pm 2.42$ \\
ALT, MU/L & $17.8 \pm 1.64$ & $18.9 \pm 3.2$ \\
AST, MU/L & $74.0 \pm 9.7$ & $73.7 \pm 7.4$ \\
Alkaline phosphatase, MU/L & $67.4 \pm 9.9$ & $71.03 \pm 8.4$ \\
Total cholesterol, mM/L & $5.21 \pm 0.31$ & $3.84 \pm 0.35^{*}$ \\
Glucose, mM/L & $3.38 \pm 0.12$ & $2.4-7.5 \mathrm{mM} / \mathrm{L}$ \\
\hline
\end{tabular}

${ }^{\Delta}$ Normal values of biochemical parameters have been taken from the Handbook "Guidelines for balanced feeding of dairy cattle" (L. K. Ernst Institute of animal husbandry, 2016). ${ }^{*} \leq 0.05$. ALT: Alanine aminotransferase, AST: Aspartate aminotransferase

Table 4: Content of macroelements in the blood of experimental cows

\begin{tabular}{llll}
\hline Indicator & \multicolumn{2}{c}{ Group } & \multirow{2}{*}{ Norm $^{\mathbf{2}}$} \\
\cline { 2 - 3 } & Reference & Experimental & \\
\hline Calcium, mM/L & $2.4 \pm 0.06$ & $2.24 \pm 0.20$ & $2.06-3.16 \mathrm{mM} / \mathrm{L}$ \\
Phosphorus, mM/L & $2.2 \pm 0.13$ & $2.3 \pm 0.4$ & $1.13-2.91 \mathrm{mM} / \mathrm{L}$ \\
Calcium/ & 1.09 & 0.97 & $0.82-2.39$ \\
phosphorus ratio & & & \\
Magnesium, mM/L & $1.09 \pm 0.07$ & $1.25 \pm 0.08$ & $0.75-1.34 \mathrm{mM} / \mathrm{L}$ \\
Iron, $\mu \mathrm{M} / \mathrm{L}$ & $20.94 \pm 2.14$ & $21.52 \pm 1.53$ & $12.9-37.1 \mathrm{mM} / \mathrm{L}$ \\
\hline
\end{tabular}

Table 5: Hematological parameters of cows that received and did not receive CES

\begin{tabular}{llll}
\hline Indicators & \multicolumn{2}{l}{ Group } & \multirow{2}{*}{ Norm $^{\Delta}$} \\
\cline { 2 - 3 } & Reference & Experimental & \\
\hline Red blood cells, 10 & \\
Leukocytes, 10 $/ \mathrm{L}$ & $7.76 \pm 0.36$ & $7.9 \pm 0.4$ & $5.0-8.0101^{2} / \mathrm{L}$ \\
Hemoglobin, g/L & $11.0 \pm 0.24$ & $10.64 \pm 0.21$ & $4.5-12.010^{9} / \mathrm{L}$ \\
Hematocrit, \% & $92.5 \pm 0.63$ & $97.9 \pm 4.1$ & $82-121 \mathrm{~g} / \mathrm{L}$ \\
\hline
\end{tabular}

CES: Coniferous energy supplement

Table 6: Indicators of non-specific resistance in the blood of experimental cows

\begin{tabular}{lll}
\hline Indicator & Group \\
\cline { 2 - 3 } & Reference & Experimental \\
\hline BABS, \% & $58.54 \pm 1.15$ & $59.03 \pm 0.54$ \\
LABS, \% & $12.67 \pm 1.20$ & $21.54 \pm 4.7$ \\
PA, \% & $11.1 \pm 0.52$ & $13.02 \pm 1.13$ \\
PI & $1.60 \pm 0.18$ & $1.40 \pm 0.07$ \\
PN & $0.18 \pm 0.01$ & $0.182 \pm 0.01$ \\
Lysozyme, $\mu$ g/ml of serum & $0.37 \pm 0.01$ & $0.50 \pm 0.07$ \\
Specific units of lysozyme activity, & $0.88 \pm 0.05$ & $1.34 \pm 0.22$ \\
units of activity/mg of protein & & \\
\hline
\end{tabular}

PI: Phagocytic index, PN: Phagocytic number, BABS: Bactericidal activity in blood serum, LABS: Lysozyme activity in blood serum, PA: Phagocytic activity

increased by $17.3 \%$, concentration of lysozyme increased by $18.5 \%$, and bactericidal activity of blood serum increased slightly. Changes of such indicators as PA, phagocytic index, and phagocytic number had equivocal nature. Therefore, fluctuations in the non-specific reactivity of experimental cows signify that the use of the preparation does not result in pronounced changes in organism resistance to pathogenic influences, regardless of their nature - non-specific resistance.
Table 7: Content of microbial mass in the content of the rumen $(M \pm m, n=5)$

\begin{tabular}{llll}
\hline \multirow{2}{*}{ Group } & \multicolumn{3}{l}{ In $\mathbf{1 0 0} \mathbf{~ m l}$ of rumen content, mg } \\
\cline { 2 - 4 } & Bacteria & Animalculines & Total \\
\hline Reference & $253.3 \pm 20.1$ & $125.1 \pm 16.8$ & $378.4 \pm 34.8$ \\
Experimental & $280.5 \pm 22.3$ & $171.3 \pm 37.6$ & $451.8 \pm 56.2$ \\
\hline
\end{tabular}

Table 8: Dynamics of the parameters of rumen metabolism in experimental animals

\begin{tabular}{llll}
\hline \multirow{2}{*}{ Group } & \multicolumn{2}{l}{ Groups of animals } & \multirow{2}{*}{ Norm } \\
\cline { 2 - 3 } & Reference & Experimental & \\
\hline $\mathrm{pH}$ & $6.39 \pm 0.14$ & $6.11 \pm 0.14$ & $6.0-7.3$ \\
Ammonia, mg\% & $13.75 \pm 1.01$ & $13.07 \pm 0.7$ & $6.5-30$ \\
Total content of & $156.3 \pm 12.5$ & $169.9 \pm 7.5$ & \\
VFA, Mmol/g & & & \\
Acetate, \% & $65.2 \pm 1.3$ & $66.0 \pm 0.8$ & $55-75$ \\
Propionate, \% & $22.0 \pm 0.9$ & $21.4 \pm 0.7$ & $15-25$ \\
Butyrate, \% & $13.0 \pm 0.7$ & $12.8 \pm 0.6$ & $10-17$ \\
\hline
\end{tabular}

VFA: Volatile fatty acids

Efficiency of using energy and feed nutrients in ruminant animals is directly dependent on the nature of the metabolic processes in the rumen and the microbial processes in forestomachs. Indicators of ruminal digestion are summarized in Tables 7 and 8.

The data in Table 8 show an increased total acidity of rumen content in the experimental cows, which is obviously associated with intensification of the processes of fermentation and formation of acidic metabolites in the rumen in the form of VFAs, when the cows received CES. The total amount of VFAs and end products of carbohydrate digestion in forestomachs was higher by $8.7 \%$ in the experimental cows, as compared to the animals in the experimental group. This may be the evidence of intensive hydrolysis of carbohydrates in animals that received the preparation. Considering the molar ratio of individual short-chain acids, we should note an increased share of acetic acid in experimental cows and a decreased share of propionic and butyric acids. More intensive microbiological processes in the forestomachs under the influence of CES are also manifested by increasing mass of symbiotic microorganisms in the content of rumen. A higher mass of symbiotic microflora was noted in the experimental animals - the level of microbial mass formation increased by $19.4 \%$ including ciliates (by $36.9 \%$ ) and bacteria (by 10.7\%). Thus, the CES introduction was accompanied by increasing the total mass of the symbiotic microflora, both animalculines and bacteria. However, these changes were unreliable. 


\section{DISCUSSION}

Balancing of the rations can be ensured not only through the introduction of deficient components but also through the use of feed additives that increase efficiency of fodder digestion. Biologically active preparations ensure more complete extraction of nutrients from the fodder, normalize work of the digestive system, and allow satisfying the physiological needs of the organism[5-7].

In the search for new vitamin carriers for livestock and poultry breeding, attention was drawn to needle foliage as a feed additive, which is widely used. By the most valuable components - protein, extractive substances, and fat, needle foliage is superior to grass, being inferior only in ash content.

According to various authors, digestibility of organic matter of natural pine needles is in the range between $24 \%$ and $80 \%$, i.e., needles are highly nutritious and easily digested. Pine needles contain carotene, chlorophyll, xanthophyll, and other substances that play a role in metabolism and in the synthesis of several new vitamins in the organism, whereby the content of carotene, which is provitamin A, in the needles, is two times higher than that in carrots. In winter and autumn, lack of vitamins could be rectified by adding pine and spruce needles to the diet, which are rich in vitamins A, C, B2, K, E, P. Thus, $1 \mathrm{~kg}$ of green needles contains, mg:pine:carotene - 60-130, Vitamin C - 3000, Vitamin K - 20, Vitamin B2 - 5; spruce: carotene - 50-120; Vitamin C - 2500, Vitamin K - 12, Vitamin B2 - 5. Pine and spruce needles contain iron, manganese, copper, zinc, cobalt, potassium, sodium, calcium, etc. $[8,9]$ The high content of cobalt in the needles explains the therapeutic effect of feeding them to cattle that suffers from tabes. Besides, needles contain resinous substances, volatile oils, and phytoncids that have bacteriostatic effect on the intestinal microflora. The use of pine and spruce needles in the amount of 0.1-0.2 kg per head per day as a vitamin additive increases the daily weight gain in pigs by $13 \%-35 \%$, as compared to the weight gain in animals that did not receive the additive. Feeding needles to domestic animals, chicken, and hens helps prevent vitamin deficiency and increases their productivity. Feeding pine needles decreases meat yield and does not impair its quality. The use of fresh crushed needles in the experiments with young cattle has reduced feed costs per unit of production by $5 \%-10 \%$, as compared to the reference data[10-13]. The efficiency of feeding the biologically active additive containing pine extract and glycerin has been fully substantiated in this study.

\section{CONCLUSIONS}

Feeding CES in the amount of $150 \mathrm{~g} /$ head per day to cows in the late dry/early lactation period resulted in an increased average daily yield of milk with natural fat content by 5.4\%-6.9\% and in a reduced cost of fodder per head. The use of the preparation contributed to improving fermentative processes in the rumen, which was manifested in increased formation of VFAs, and level of microbial mass formation increased by $19.4 \%$, including increased ciliates and bacteria by $36.9 \%$ and $10.7 \%$, respectively. Introduction of the studied preparation into the diet had a positive effect on carbohydrate-and-fat and protein metabolism in cows, which was manifested in an increased concentration of albumin $5.5 \%$, glucose $9.5 \%$ with reduced content of urea by $27.2 \%$, creatinine by $5.2 \%$, and cholesterol by $26.3 \%$. In the blood of cows that received the CES, a higher content of hemoglobin (by 5.8\%), hematocrit, and erythrocytes and a slightly lower content of leukocytes were noted, as compared with the cows in the reference group, which is an evidence of the absence of toxic effect of the preparation. The use of CES in the diet of cows in the late dry/early lactation period helped to increase the phagocytic and lysozyme activity in the blood serum. To maintain productive health, to reduce the effects of the post-calving stress, and to increase milk productivity of animals, it is recommended to use the CES in the diet of cows in the late dry/early lactation period.

\section{REFERENCES}

1. Buryakov NP. Monitoring adequacy of cattle diet. Biology 2008;7:11.

2. Tao S, Monteiro AP, Hayen MJ, Dahl GE. Short communication: Maternal heat stress during the dry period alters postnatal whole-body insulin response of calves. J Dairy Sci 2014;97(2):897-901.

3. Shaposhnikov AA, Afanasiev PI, Altukhov AA, Martynova IA, Ilyushchenko SV. Some metabolic parameters in calves when used in rations of malt. Magazine scientific bulletin of the Belgorod State University. Ser Nat Sci 2012;21:123-6.

4. Zayats VN, Kvetkovskaya AV, Nadeinskaya MA. Feeding propylene glycol to high yielding cows in combination with niacin and glycerin. Feed Agric Anim Fodder Prod 2009;1:20-3.

5. Acharya K, Paloi S. Evaluation of antioxidative activity and chemical composition of ethanolic extract from Amanita vaginata (Bull.) Lam.: An in vitro study. Asian J Pharm Clin Res 2014;7:88-92.

6. Henning A. Minerals, vitamins, biostimulants in feeding farm animals. Moscow: Kolos; 1986.

7. Ganugapati J, Swarna S. Molecular docking studiesof antidiabetic activity of cinnamon compounds. Asian J Pharm Clin Res 2014;7 Suppl 2:31-4

8. Ebrahimi L, Kiran KG, Ayub Nawaz KA, Subashchandrabose V, Durairaju NS, Palaniswamy M, et al. Isolation of angiotensinconverting enzyme inhibitor producing bacteria from cow milk. Int $\mathrm{J}$ Pharm Pharm Sci 2016;8:183-6.

9. Ananya, Kamal A. Fatty acid profiling and antioxidant potential of total polar lipid content of cyanobacterium Nostoc muscorum. Int J Pharm Pharm Sci 2016;8:183-6.

10. Ryzhov VA, Ryzhova ES, Korotky PV, Zenkin AS, Marisov SS. Development and industrial application of domestic phytobiotics. Sci Methodical Electron J Concept 2015;13:3236-40.

11. Alabdallat NG. In vitro anti-sickling activity of Artemisia herba-alba asso (Chih) methanolic estract on sickle cell disease. Asian J Pharm Clin Res 2016;9 Suppl 1:109-12.

12. Korotky VP, Ryzhov VA, Marisov SS, Zenkin AS, Esipovich AL. Technologies of Processing Wood Foliage - New Approaches, Part 2. In the Proceedings of the III International Scientific and Practical Conference: Innovations and Technologies in Forestry - 2013. St. Petersburg, Federal State-Funded Institution St. Petersburg Forestry Research Institute (SPFRI); 2013. p. 24-36.

13. Lee V. Optimization of digestive processes in cows. Dairy Beef Cattle Breed 2011;7:8-10. 